\title{
KARAKTERISTIK KOMPOSIT BIOPLASTIK GLUKOMANAN DAN MAIZENA DALAM PENGARUH VARIASI SUHU DAN WAKTU GELATINISASI
}

Characteristics of Composites Bioplastic Glucomannan and Maizena in the Variation of Temperature and Gelatinization Time

\author{
Cintia Indrawati, Bambang Admadi Harsojuwono*, Amna Hartiati \\ PS Teknologi Industri Pertanian, Fakultas Teknologi Pertanian, Universitas Udayana, Kampus Bukit \\ Jimbaran, Badung, Kode pos : 80361; Telp/Fax : (0361) 701801.
}

Diterima 10 Juni 2019 / Disetujui 03 Juli 2019

\begin{abstract}
The aim of this study was to determine the effect of the temperature and time of gelatinization and its interactions on the composite characteristics of bioplastics glucomannan and cornstarch with to obtain gelatinization temperature and time to produce the best bioplastic glucomannan and cornstarch composites. This study used factorial randomized block design. Factor 1 gelatinization temperature consisting of 3 levels, namely $70 \pm 1 ; 75 \pm 1 ; 80 \pm 1{ }^{\circ} \mathrm{C}$. Factor 2 is gelatinization time, for 2,3 and 4 minutes. Variables observed included tensile strength, elongation at break, young modulus, swelling, biodegradation and functional group profile. The data were analyzed for diversity and continued with the BNJ test. The results showed that the temperature and time of gelatinization and their interactions had a very significant effect on tensile strength and elasticity. The temperature and time of gelatinization had a very significant effect but did not interact with elongation and did not significantly affect the swelling and biodegradation of bioplastic composites. The best bioplastic glucomannan and maizene composites were at a temperature treatment of $80 \pm 1^{\circ} \mathrm{C}$ and 4 minutes gelatinization time with tensile strength characteristics (3.390 mpa); elasticity (35.811 mpa); elongation at break (12.3\%); swelling (68.13\%); degradation time of 8 days and contains hydroxyl $(\mathrm{O}-\mathrm{H})$ functional groups, alkene $(\mathrm{C}-\mathrm{H})$, carboxyl $(C-O)$, carbonyl $(C=O)$ and alkyne $(C \equiv C)$.
\end{abstract}

Keywords : Composites bioplastic, glucomannan, maizena, temperature and time of gelatinization

\begin{abstract}
ABSTRAK
Penelitian ini bertujuan untuk mengetahui pengaruh pengaturan suhu dan waktu gelatinisasi serta interaksinya terhadap karakteristik komposit bioplastik glukomanan dan maizena serta mendapatkan suhu dan waktu gelatinisasi yang tepat sehingga menghasilkan komposit bioplastik glukomanan dan maizena dengan karakteristik yang terbaik. Penelitian ini menggunakan rancangan acak kelompok dua faktorial. Faktor 1 suhu gelatinisasi yang terdiri dari 3 taraf yaitu $70 \pm 1 ; 75 \pm 1 ; 80 \pm 1^{\circ} \mathrm{C}$. Faktor 2 yaitu waktu gelatinisasi yaitu selama 2, 3 dan 4 menit. Variabel yang diamati meliputi kekuatan tarik, perpanjangan saat putus, elastisitas, swelling, biodegradasi dan profil gugus fungsi. Data dianalisis keragamannya dan dilanjutkan dengan uji BNJ. Hasil penelitian menunjukkan bahwa suhu dan waktu gelatinisasi serta interaksinya berpengaruh sangat nyata terhadap kuat tarik dan elastisitas. Suhu dan
\end{abstract}

*Korespondensi Penulis:

Email : bambang.admadi@unud.ac.id 
waktu gelatinisasi berpengaruh sangat nyata namun tidak berinteraksi terhadap perpanjangan saat putus serta tidak berpengaruh nyata terhadap swelling dan biodegradasi komposit bioplastik. Komposit bioplastik glukomanan dan maizena terbaik yaitu pada perlakuan suhu $80 \pm 1^{\circ} \mathrm{C}$ dan lama gelatinisasi 4 menit dengan karakteristik kuat tarik (3,390 MPa); elastisitas (35,811 MPa); perpanjangan saat putus $(12,3 \%)$; swelling $(68,13 \%)$; waktu degradasi 8 hari dan mengandung gugus fungsi hidroksil $(\mathrm{O}-\mathrm{H})$, alkena $(\mathrm{C}-\mathrm{H})$, karboksil $(\mathrm{C}-\mathrm{O})$, karbonil $(\mathrm{C}=\mathrm{O})$ dan alkuna $(\mathrm{C} \equiv \mathrm{C})$.

Kata kunci : Komposit bioplastik, glukomanan, maizena, suhu dan waktu gelatinisasi

\section{PENDAHULUAN}

Penggunaan produk berbahan dasar plastik mengakibatkan makin banyaknya jumlah sampah plastik dilinngkungan. Menurut Menteri Kelautan dan Perikanan dalam Puspita (2018) Indonesia merupakan negara penyumbang sampah plastik ke lautan terbesar kedua di dunia. Perkembangan teknologi menyebabkan semakin beragamnya penelitian mengenai plastik dengan bahan alami yang biodegradable. Bioplastik dapat digunakan sebagai alternatif produk plastik yang ramah lingkungan.

Bioplastik dapat terbentuk dari berbagai jenis umbi yang mengandung pati. Tepung maizena mempunyai kandungan 74 $76 \%$ amilopektin serta $24-26 \%$ amilosa. Kandungan amilosa pada tepung maizena lebih besar dibandingkan dengan tapioka dan sorgum yaitu 20\% dan 17\% (Radhiyatullah dkk, 2015). Kadar amilosa yang tinggi dapat menurunkan kemampuan pati untuk tergelatinisasi tetapi dapat diimbangi dengan adanya kandungan amilopektin yang lebih tinggi pada maizena (Carpenter dkk, 1990). Kandungan amilopektin dapat mempengaruhi sifat kelarutan dan derajat gelatinisasi pati (Nisah, 2017). Amilopektin mempunyai struktur rantai bercabang dan amilosa berstruktur lurus (Sakinah dan Kurniawansyah, 2018). Menurut Syach (1974) struktur rantai cabang amilopektin jika ditambahkan dengan komposit glukomanan dapat membentuk ikatan silang karena terdapat gugus asetil yang membentuk cabang dan berkumpul hingga memungkinkan membentuk ikatan yang semakin kuat. Menurut Harsojuwono dkk,
(2018) Rasio pati singkong termodifikasi dan glukomanan $(1,5: 4,5 \mathrm{~g})$ dengan larutan asam cuka $1 \%$ (93 g) dan gliserol $1 \mathrm{~g}$ merupakan perlakuan rasio terbaik yang dilakukan. Penelitian tersebut dijadikan sebagai dasar penentuan rasio komposit glukomanan dan maizena.

Faktor yang dapat mempengaruhi hasil pembentukan komposit dari bahan glukomanan dan maizena adalah suhu dan waktu gelatinisasi. Suhu gelatinisasi pati dapat mempengaruhi perubahan viskositas larutan pati. Peningkatan suhu dapat meningkatkan kelarutan pati, granula pati yang dipanaskan dengan rentang suhu tertentu hingga mencapai suhu gelatinisasinya mengakibatkan granula akan membentuk pasta pati yang kental yang berupa granula pati bengkak seperti gel yang bersifat elastis (Nisah, 2017). Sementara itu pengaturan suhu gelatinisasi glukomanan dapat pula mempengaruhi ikatan yang terbentuk dengan rentang suhu $43-95^{\circ} \mathrm{C}$. Penentuan suhu dan waktu gelatinisasi dilakukan dengan penelitian pendahuluan dengan hasil perlakuan suhu $75 \pm 1^{\circ} \mathrm{C}$ dan waktu gelatinisasi 3 menit serta rasio komposit glukomana dan maziena 1,5 : 4,5 yang menghasilkan komposit bioplastik glukomanan dan maizena. Menurut Harsojuwono dkk, (2018) suhu gelatinisasi $75 \pm 1^{\circ} \mathrm{C}$ pada ph 5 bioplastik pati singkong termodifikasi, menghasilkan nilai kuat tarik tertinggi $(1657,43 \mathrm{mpa})$. Sementara itu, Pradipta dan Mawarni (2012) suhu $90^{\circ} \mathrm{C}$ menghasilkan nilai kuat tarik bioplastik glukomanan dari umbi porang tertinggi $(0,800 \pm 0,45 \mathrm{mpa})$. Penelitian tersebut menunjukkan bahwa belum adanya informasi 
mengenai karakteristik komposit bioplastik glukomanan dan maizena dalam variasi suhu dan waktu gelatinisasi, sehingga perlu dilakukan penelitian.

Tujuan penelitian ini, adalah mengetahui pengaruh pengaturan suhu dan waktu gelatinisasi serta interaksinya terhadap karakteristik komposit bioplastik glukomanan dan maizena serta mendapatkan suhu dan waktu gelatinisasi yang tepat sehingga menghasilkan komposit bioplastik glukomanan dan maizena dengan karakteristik terbaik.

\section{METODE PENELITIAN}

\section{Bahan dan Alat}

Bahan yang digunakan untuk melakukan penelitian terdiri dari bahan baku dan bahan kimia. Bahan baku yang digunakan yaitu tepung maizena (Hagai) dan glukomanan dari umbi porang (Konjac) yang diperoleh dari CV. Nura Jaya, Malang serta bahan kimianya yaitu aquades (Adesta), asam asetat glacial PA 99,6\% (Emsure) dan gliserol PA (Emsure).

Peralatan yang digunakan untuk melakukan penelitian yaitu batang pengaduk, sendok, gelas ukur, pinset, cetakan teflon dengan diameter $20 \mathrm{~cm}$, gelas beaker $100 \mathrm{ml}$ dan $250 \mathrm{ml}$, pipet tetes, termometer, kompor gas, panci, timbangan analitik, oven, alat uji kompresi dan ketegangan universal dan FTIR Spektrometer.

\section{Pelaksanaan Penelitian}

Proses pembuatan komposit bioplastik dilakukan dengan beberapa tahapan. Tahap pertama yaitu mempersiapkan bahan baku dan bahan kimia yang dibutuhkan untuk membuat komposit bioplastik yaitu glukomanan, maizena, gliserol dan larutan asam asetat $1 \%$. Tahapan kedua dilakukan penimbangan bahan dengan massa bahan yaitu glukomanan $1,5 \mathrm{~g}$; maizena $4,5 \mathrm{~g}$; asam asetat $1 \% \quad(93 \mathrm{~g})$. Tahapan selanjutnya glukomanan dan maizena yang telah ditimbang dimasukkan ke dalam beaker glass, kemudian ditambahkan asam asetat $1 \%$ dan diaduk dengan menggunakan batang pengaduk selama \pm 15 menit hingga campuran bahan menjadi homogen kemudian dilakukan proses pemanasan dengan menggunakan kompor pada suhu sesuai perlakukan hingga membentuk gel campuran glukomanan dan maizena (Harsojuwono dan Arnata, 2016). Campuran yang telah menjadi gel kemudian dimasukkan ke dalam cetakan teflon berukuran $20 \mathrm{~cm}$ yang selanjutnya dipanaskan pada oven dengan suhu $60^{\circ} \mathrm{C}$ selama 12 jam. Gel yang telah mengering didiamkan pada suhu ruang selama 24 jam hingga dingin (Harsojuwono dkk, 2017).

\section{Variabel yang Diamati}

Variabel yang diamati pada penelitian ini yaitu sifat mekanik bioplastik yang terdiri dari kekuatan tarik (Tensile strength) (Lazuardi dkk, 2013; Rifaldi dkk, 2017), perpanjangan (elongation) (Safitri, 2016; Rifaldi dkk, 2017), elastisitas (Modulus Young) (Rifaldi dkk, 2017), uji pengembangan (swelling) (illing dan satriawan 2018), kemampuan biodegradasi (Lazuardi dkk, 2013) dan uji profil gugus fungsi (Nasution dan Rambe, 2013).

\section{HASIL DAN PEMBAHASAN}

\section{Kuat Tarik (Tensile Srength)}

Berdasarkan hasil analisis keragaman menunjukkan bahwa suhu dan waktu gelatinisasi serta interaksinya berpengaruh sangat nyata $(\mathrm{p}<0.01)$ terhadap kuat tarik bioplastik dari komposit glukomanan dan maizena. Nilai kuat tarik dari komposit glukomanan dan maizena berkisar antara 1,830 - 3,390 MPa yang dapat dilihat pada Tabel 1. 
Tabel 1. Nilai kuat tarik bioplastik dari komposit glukomanan dan maizena

\begin{tabular}{cccc}
\hline \multirow{2}{*}{ Suhu } & \multicolumn{3}{c}{ Waktu } \\
\cline { 2 - 4 } & 2 menit & $(3$ menit $)$ & $(4$ menit $)$ \\
\hline $70 \pm 1^{\circ} \mathrm{C}$ & $1,830 \pm 0,071 \mathrm{~d}$ & $1,935 \pm 0,0636 \mathrm{~d}$ & $2,065 \pm 0.1061 \mathrm{~d}$ \\
$75 \pm 1^{\circ} \mathrm{C}$ & $2,445 \pm 0,163 \mathrm{c}$ & $2,925 \pm 0,0778 \mathrm{~b}$ & $3,035 \pm 0,1202 \mathrm{~b}$ \\
$80 \pm 1^{\circ} \mathrm{C}$ & $2,535 \pm 0,163 \mathrm{c}$ & $3,040 \pm 0,141 \mathrm{~b}$ & $3,390 \pm 0,0707 \mathrm{a}$ \\
\hline
\end{tabular}

Keterangan: huruf yang berbeda di belakang nilai rata-rata menunjukkan perbedaan yang nyata pada taraf kesalahan 5\%

Kuat tarik menunjukkan nilai maksimum gaya yang diperoleh jika dilakukan uji tarik. Bioplastik dengan kekuatan tarik yang tinggi akan mampu melindungi produk yang dikemasnya dari gangguan mekanis dengan baik (Hasanah dan Hartoyo, 2017). Tabel 1 menunjukkan bahwa nilai kuat tarik tertinggi $(3,390 \mathrm{MPa})$ dimiliki komposit bioplastik glukomanan dan maizena yang dibuat dengan suhu gelatinisasi $80 \pm 1^{\circ} \mathrm{C}$ dengan waktu gelatinisasi 4 menit yang berbeda nyata dengan lainnya. Kuat tarik yang terendah dimiliki komposit bioplastik glukomanan dan maizena yang diatur pada suhu $70 \pm 1^{\circ} \mathrm{C}$ dengan waktu 2,3 dan 4 menit dengan kisaran nilai 1,830 2,065 MPa. Tabel 1 menunjukkan bahwa semakin tinggi suhu dan waktu gelatinisasi menyebabkan nilai kuat tarik bioplastik semakin tinggi. Hal tersebut dikarenakan kandungan pati yang terdapat pada tepung maizena dengan penambahan glukomanan dan sejumlah larutan asam asetat dengan perlakuan suhu yang semakin tinggi dan lama waktu dengan kisaran tertentu mengakibatkan granula pati akan menyerap air hingga membengkak akibat suhu panas air dan memungkinkan ikatan amilopektin yang tinggi pada maizena akan cenderung saling berikatan dan membentuk ikatan silang karena adanya gugus asetil pada glukomanan yang bergabung dan menjadi lebih rapat sehingga komposit yang dihasilkan semakin kuat (Winarno, 1997; Maekaji, 1974). Jerman Institute for Standardization (2014) tentang ISO 527/1B komposit polimer serat alami, standar nilai kuat tarik bioplastik sebesar 35,95 MPa. Besaran nilai kuat tarik komposit bioplastik glukomanan dan maizena belum memenuhi standar kuat tarik ISO 527/1B.

\section{Perpanjangan Saat Putus (Elongation at Break)}

Berdasarkan hasil analisis keragaman menunjukkan bahwa suhu dan waktu gelatinisasi berpengaruh sangat nyata $(\mathrm{p}<0,01)$ sedangkan interaksinya tidak berpengaruh nyata terhadap perpanjangan saat putus (elongation at break) bioplastik komposit glukomanan dan maizena. Nilai perpanjangan saat putus komposit glukomanan dan maizena berkisar antara $11,5 \%-19,1 \%$ yang dapat dilihat pada Tabel 2.

Tabel 2. Nilai perpanjangan saat putus (\%) bioplastik komposit glukomanan dan maizena

\begin{tabular}{ccccc}
\hline \multirow{2}{*}{ Suhu } & \multicolumn{3}{c}{ Waktu } & \multirow{2}{*}{ Rerata } \\
\cline { 2 - 4 } & 2 menit & 3 menit & 4 menit & \\
\hline $70 \pm 1^{\circ} \mathrm{C}$ & $24,0 \pm 0.0141$ & $19,0 \pm 0.0141$ & $13,5 \pm 0.0071$ & $18,8 \mathrm{a}$ \\
$75 \pm 1^{\circ} \mathrm{C}$ & $18,0 \pm 0.014$ & $15,5 \pm 0.00707$ & $11,5 \pm 0.0071$ & $15,0 \mathrm{~b}$ \\
$80 \pm 1^{\circ} \mathrm{C}$ & $15,5 \pm 0.0212$ & $12,0 \pm 0.0141$ & $09,5 \pm 0.0900$ & $12,3 \mathrm{c}$ \\
\hline Rerata & $19,1 \mathrm{a}$ & $15,5 \mathrm{~b}$ & $11,5 \mathrm{c}$ &
\end{tabular}

Keterangan: huruf yang berbeda di belakang nilai rata-rata menunjukkan perbedaan yang nyata pada taraf kesalahan 5\%

Perpanjangan saat putus merupakan persen pertambahan panjang bahan materi film yang diukur mulai dari panjang awal pada saat mengalami penarikan hingga putus 
(Hasanah dan Haryanto, 2017). Tabel 2 menunjukkan bahwa rata-rata persen perpanjangan saat putus dari bioplastik komposit glukomanan dan maizena pada suhu gelatinisasi $70 \pm 1^{\circ} \mathrm{C}$ menghasilkan nilai tertinggi $(18,8 \%)$ yang berbeda nyata dengan suhu $75 \pm 1^{\circ} \mathrm{C}$ maupun $80 \pm 1^{\circ} \mathrm{C}$. Sementara itu suhu $80 \pm 1^{\circ} \mathrm{C}$ memberikan nilai terendah yang berbeda nyata dengan lainnya. Tabel 2 juga menunjukkan bahwa rata-rata nilai persen perpanjangan tertinggi $(19,1 \%)$ dimiliki bioplastik komposit glukomanan dan maizena yang menggunakan waktu gelatinisasi selama 2 menit yang berbeda dengan lainnya. Sementara itu rata-rata persen perpanjangan terendah $(11,5 \%)$ dimiliki bioplastik komposit glukomanan dan maizena yang menggunakan waktu gelatinisasi selama 4 menit yang berbeda nyata dengan lainnya. Nilai persentase ratarata terbesar pada suhu rendah dikarenakan pengaturan suhu rendah akan menghasilkan komposit bioplastik dengan struktur yang kurang rapat, kandungan air dalam bahan lebih banyak dibanding pengaturan suhu yang lebih tinggi sehingga rata-rata nilai perpanjangan yang dihasilkan lebih tinggi dibandingkan dengan suhu yang tinggi (Pradipta dan Mawarni, 2012). Sementara itu pada pengaturan waktu dengan durasi terkecil menghasilkan rata-rata nilai perpanjangan saat putus terbesar dikarenakan pada durasi gelatinisasi 2 menit (terkecil) gel glukomanan yang dihasilkan memungkinkan belum homogen dan strukturnya kurang rapat sehingga hasil perpanjangan saat putus yang dihasilkan paling tinggi dibanding perlakuan waktu yang lain (Pradipta dan Mawarni, 2012). Menurut Standar Nasional Indonesia standar (2014) nilai perpanjangan saat putus bioplastik sebesar 21-220\%. Nilai perpanjangan saat putus komposit bioplastik glukomanan dan maizena dengan perlakuan suhu dan waktu gelatinisasi belum sesuai dengan SNI.

\section{Elastisitas (Modulus Young)}

Berdasarkan hasil analisis keragaman menunjukkan bahwa suhu dan lama waktu gelatinisasi berpengaruh sangat nyata $(\mathrm{p}<0.01)$ terhadap elastisitas bioplastik dari komposit glukomanan dan maizena serta interaksinya berpengaruh nyata terhadap elastisitas bioplastik komposit glukomanan dan maizena. Nilai elastisitas dari bioplastik komposit glukomanan dan maizena berkisar antara

7,629 - 35,811 MPa yang dapat dilihat pada Tabel 3.

Tabel 3. Nilai elastisitas bioplastik dari komposit glukomanan dan maizena.

\begin{tabular}{cccc}
\hline \multirow{2}{*}{ Suhu } & \multicolumn{3}{c}{ Waktu gelatinisasi } \\
\cline { 2 - 4 } & 2 menit & 3 menit & W3 (4 menit) \\
\hline $70 \pm 1^{\circ} \mathrm{C}$ & $7,629 \pm 0,155 \mathrm{f}$ & $10,200 \pm 0,424 \mathrm{ef}$ & $15,296 \pm 0,015 \mathrm{de}$ \\
$75 \pm 1^{\circ} \mathrm{C}$ & $13,661 \pm 1,980 \mathrm{def}$ & $18,879 \pm 0,359 \mathrm{~cd}$ & $26,473 \pm 2,670 \mathrm{~b}$ \\
$80 \pm 1^{\circ} \mathrm{C}$ & $16,581 \pm 3,320 \mathrm{de}$ & $25,580 \pm 4,190 \mathrm{bc}$ & $35,811 \pm 3,410 \mathrm{a}$ \\
\hline
\end{tabular}

Keterangan: huruf yang berbeda di belakang nilai rata-rata menunjukkan perbedaan yang nyata pada taraf kesalahan $5 \%$

Elastisitas merupakan pengujian yang dilakukan untuk mengetahui ukuran kekakuan dari bahan yang dihasilkan. Nilai elastisitas diperoleh dari hasil perbandingan dari kuat tarik dan perpanjangan saat putus (perpanjangan saat putus) (Arini dkk, 2017). Tabel 3 menunjukkan bahwa nilai elastisitas tertinggi $(35,811 \mathrm{MPa})$ dari bioplastik komposit glukomanan dan maizena pada suhu gelatinisasi $80 \pm 1^{\circ} \mathrm{C}$ dengan waktu gelatinisasi 4 menit yang berbeda dengan lainnya. Nilai elastisitas terendah (7.629 $\mathrm{MPa}$ ) terdapat pada suhu gelatinisasi $70 \pm 1^{\circ} \mathrm{C}$ dengan waktu gelatinisasi selama 2 menit yang tidak berbeda nyata dengan elastisitas komposit bioplastik yang diatur pada suhu 
$70 \pm 1^{\circ} \mathrm{C}$ dengan waktu 3 menit dan $75 \pm 1^{\circ} \mathrm{C}$ dengan waktu 2 menit. Tabel 3 juga menunjukkan terjadinya peningkatan nilai elastisitas seiring dengan penambahan suhu dan waktu gelatinisasi. Hal tersebut dikarenakan nilai elastisitas dipengaruhi oleh perpanjangan saat putus dan kuat tarik, sehingga semakin besar nilai kuat tarik dan perpanjangan saat putus maka nilai elastisitas akan semakin besar dan bahan semakin elastis (Hayati dan Lazulva, 2018). Penambahan suhu dan waktu yang semakin tinggi dengan suhu tertentu sesuai dengan rentang suhu gelatinisasi bahan mengakibatkan ikatan molekul pembentuk pati akan saling berdekatan akibat ikatan hidrogen yang terjadi pada penambahan sejumlah air (Wahyu, 2008). Menurut Jerman
Institute for Standardization (2014) tentang ISO 527/1B komposit polimer serat alami, standar nilai elastisitas sebesar $6019 \mathrm{MPa}$. Nilai komposit bioplastik glukomanan dan maizena yang diperoleh belum memenuhi standar ISO 527/1B.

\section{Pengembangan (Swelling)}

Berdasarkan hasil analisis keragaman menunjukkan bahwa suhu dan lama waktu gelatinisasi, serta interaksinya tidak berpengaruh nyata terhadap penggembungan (swelling) bioplastik komposit glukomanan dan maizena $(\mathrm{P}>0,05)$. Nilai swelling komposit glukomanan dan maizena berkisar antara $66,96 \%$ - 103,37\% yang dapat dilihat pada Tabel 4.

Tabel 4. Persentase swelling (\%) komposit glukomanan dan maizena

\begin{tabular}{cccc}
\hline \multirow{2}{*}{ Suhu } & \multicolumn{3}{c}{ Waktu } \\
\cline { 2 - 4 } & 2 menit & 3 menit & W3 (4 menit $)$ \\
\hline $70 \pm 1^{\circ} \mathrm{C}$ & $89,40 \pm 0,0601 \mathrm{a}$ & $82,48 \pm 0,0343 \mathrm{a}$ & $80,73 \pm 0,2280 \mathrm{a}$ \\
$75 \pm 1^{\circ} \mathrm{C}$ & $89,78 \pm 0,0418 \mathrm{a}$ & $103,37 \pm 0,1440 \mathrm{a}$ & $67,50 \pm 0,2730 \mathrm{a}$ \\
$80 \pm 1^{\circ} \mathrm{C}$ & $100,7 \pm 0,0967 \mathrm{a}$ & $66,96 \pm 0,2610 \mathrm{a}$ & $68,13 \pm 0,0735 \mathrm{a}$ \\
\hline
\end{tabular}

Keterangan: huruf yang berbeda di belakang nilai rata-rata menunjukkan perbedaan yang nyata pada taraf kesalahan $5 \%$

Menurut Saputro dkk, (2014) glukomanan mempunyai sifat istimewa yang dapat mengalami pengembangan dengan daya mengembang yang besar. Glukomanan mampu mengembang dalam air 138\% 200\% (Widjanarko dkk, 2015). Berbeda dengan pengembangan pada pati yang lebih rendah dibandingan dengan glukomanan, granula pati akan menyerap air dan membengkak tetapi pembengkakannya terbatas sekitar $30 \%$ dari berat tepung (Anggraeni dkk, 2014). Pengaturan suhu dan waktu gelatinisasi tidak mengurangi kandungan glukomanan yang terdapat pada komposit bioplastik karena suhu dan waktu gelatinisasi hanya dapat mengaktifkan awal pemutusan ikatan pada rantai glukomanan akibat energi termal suhu gelatinisasi setelah energi yang didapat cukup sebagai pemutus ikatan, peningkatan suhu tidak berpengaruh lagi terhadap komposit bioplastik yang dibuat (Pradipta dan Mawarni, 2012). Kandungan glukomanan yang sama pada semua perlakuan suhu dan waktu gelatinisasi memungkinkan dapat menyerap air lebih besar sehingga swelling didominasi selalu. Menurut Jerman Institute for Standardization (2014) mengenai EN 317 komposit polimer serat alami, standar nilai swelling sebesar $1,44 \%$. Sesuai dengan standar tersebut komposit bioplastik glukomanan dan maziena dengan variasi suhu dan waktu gelatinisasi belum memenuhi standar EN 317.

\section{Biodegradasi}

Berdasarkan hasil analisis keragaman menunjukkan bahwa suhu dan waktu gelatinisasi, serta interaksinya tidak berpengaruh nyata terhadap lama 
biodegradasi komposit bioplastik glukomanan dan maizena $(\mathrm{P}>0,05)$. Nilai hasil uji biodegradasi bioplastik komposit glukomanan dan maizena berkisar antara 7,58,0 hari. Lama proses degradasi pada setiap perlakuan dapat dilihat pada Tabel 5.

Tabel 5. Nilai lama biodegradasi (hari) komposit glukomanan dan maizena

\begin{tabular}{cccc}
\hline \multirow{2}{*}{ Suhu } & \multicolumn{3}{c}{ Waktu } \\
\cline { 2 - 4 } & $(2$ menit $)$ & $(3$ menit $)$ & $(4$ menit $)$ \\
\hline $70 \pm 1^{\circ} \mathrm{C}$ & $7,5 \pm 0,707 \mathrm{a}$ & $7,5 \pm 0,707 \mathrm{a}$ & $8,0 \pm 0,000 \mathrm{a}$ \\
$75 \pm 1^{\circ} \mathrm{C}$ & $8,0 \pm 0,000 \mathrm{a}$ & $8,0 \pm 0,000 \mathrm{a}$ & $8,0 \pm 0,000 \mathrm{a}$ \\
$80 \pm 1^{\circ} \mathrm{C}$ & $8,0 \pm 0,000 \mathrm{a}$ & $8,0 \pm 0,000 \mathrm{a}$ & $8,0 \pm 0,000 \mathrm{a}$ \\
\hline
\end{tabular}

Keterangan : huruf yang berbeda di belakang nilai rata-rata menunjukkan perbedaan yang nyata pada taraf kesalahan $5 \%$

Ketika dilakukan penanaman dalam tanah komposit bioplastik glukomanan dan maizena, akan terjadi penyerapan air yang tinggi akibat kemampuan menyerap glukomanan yang tinggi (138-200\%) sehingga akan memungkinkan mengalami kerusakan yang hampir sama ketika terdegradasi oleh mikroba dalam tanah. Menurut standar Nasinal Indonesia (SNI) plastik biodegradable dapat terdegradasi $60 \%$ selama seminggu. Berdasarkan hal tersebut bioplastik komposit glukomanan dan maizena sudah sesuai dengan SNI karena bioplastik dapat terdegradasi $100 \%$ pada hari ke-8. Rumus fungsi linier pada biodegradasi komposit bioplastik glukomanan dan maizena dapat dilihat pada Tabel 6.

Tabel 6. Rumus fungsi linier biodegradasi bioplastik sesuai kode perlakukan

\begin{tabular}{ccc}
\hline $\begin{array}{c}\text { Perlakuan } \\
(\text { suhu dan waktu) }\end{array}$ & Perbandingan & $\begin{array}{c}\text { Determinasi } \\
\left(\mathrm{r}^{2}\right)\end{array}$ \\
\hline $70 \pm 1^{\circ} \mathrm{C}$ dan 2 menit & $\mathrm{y}=10.658 \mathrm{x}-8.9271$ & 0.8471 \\
$70 \pm 1^{\circ} \mathrm{C}$ dan 3 menit & $\mathrm{y}=10.642 \mathrm{x}-17.095$ & 0.7378 \\
$70 \pm 1^{\circ} \mathrm{C}$ dan 4 menit & $\mathrm{y}=9.5102 \mathrm{x}-19.163$ & 0.6618 \\
$75 \pm 1^{\circ} \mathrm{C}$ dan 2 menit & $\mathrm{y}=9.0317 \mathrm{x}-12.874$ & 0.6257 \\
$75 \pm 1^{\circ} \mathrm{C}$ dan 3 menit & $\mathrm{y}=8.6329 \mathrm{x}-10.606$ & 0.5713 \\
$75 \pm 1^{\circ} \mathrm{C}$ dan 4 menit & $\mathrm{y}=10.558 \mathrm{x}-24.919$ & 0.7249 \\
$80 \pm 1^{\circ} \mathrm{C}$ dan 2 menit & $\mathrm{y}=7.0999 \mathrm{x}-0.0628$ & 0.4135 \\
$80 \pm 1^{\circ} \mathrm{C}$ dan 3 menit & $\mathrm{y}=8.4971 \mathrm{x}-8.9959$ & 0.5567 \\
$80 \pm 1^{\circ} \mathrm{C}$ dan 4 menit & $\mathrm{y}=8.6419 \mathrm{x}-17.193$ & 0.5906 \\
\hline
\end{tabular}

Tabel 6 menunjukkan laju susut bobot dan hubungan keeratan antara suhu dan waktu gelatinisasi. laju susut bobot dan hubungan keeratan antara suhu dan waktu gelatinisasi tertinggi $(y=10,658 x-8,9271$ dan $\left.r^{2}=0,8471\right)$ dimiliki oleh komposit bioplastik glukomanan dan maziena dengan pengaturan suhu $70 \pm 1^{\circ} \mathrm{C}$ dengan waktu 2 menit. Nilai determinasi tertinggi menunjukkan bahwa 15,29\% bioplastik yang diuji biodegradasi dipengaruhi oleh faktor lain. Sementara itu bioplastik dengan suhu
$80 \pm 1{ }^{\circ} \mathrm{C}$ dan waktu gelatinisasi 2 menit menunjukkan laju susut bobot dan hubungan keeratan antara suhu dan waktu gelatinisasi terendah $\left(7,0999 \mathrm{x}-0,0628\right.$ dan $\left.\mathrm{r}^{2}=0,4135\right)$ dibandingkan dengan yang lainnya. Nilai determinasi terendah $(41,35 \%)$ menunjukkan bahwa $58,65 \%$ faktor yang mempengaruhi biodegradasi bioplastik berasal dari faktor lain selain suhu dan waktu gelatinisasi. Faktor lain yang memungkinkan dapat mempengaruhi persentase susut bobot dan lama degradasi bioplastik yaitu jumlah 
kandungan mikroorganisme yang terdapat pada tanah sebagai media tanam bioplastik serta kandungan air pada bioplastik dan tanah sebagai media tanam. Air dapat berfungsi sebagai media perkembangan mikroba yang terdapat dalam tanah sehingga kandungan air dapat mempercepat degradasi bioplastik (Haryanto dan Hasanah, 2017).

\section{Profil Gugus Fungsi FTIR (Fourrier Transform Infra Red)}

Bioplastik yang diuji dengan menggunakan FTIR adalah bioplastik dengan hasil kuat tarik terbaik $(3,390 \mathrm{MPa})$ dari bioplastik komposit glukomanan dan maizena dengan suhu gelatiniasi $80 \pm 1^{\circ} \mathrm{C}$ dan lama waktu gelatinisasi 4 menit. Hasil uji FTIR bioplastik komposit glukomanan dan maizena dapat dilihat pada Gambar 1.

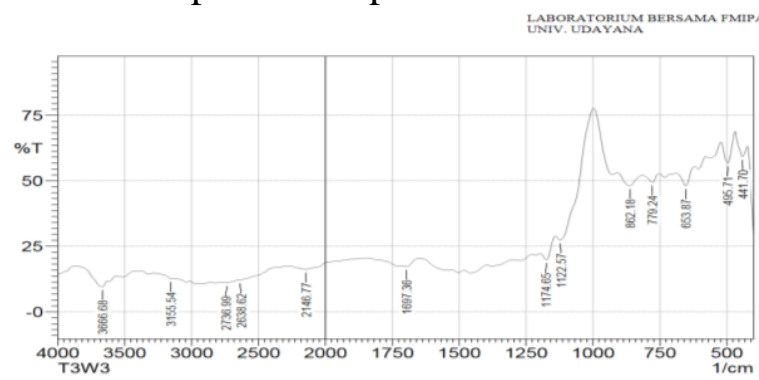

Gambar 1. Grafik bilangan gelombang bioplastik komposit glukomanan dan maizena

Gambar 1 menunjukkan gugus fungsi yang terbentuk pada bioplastik komposit glukomanan dan maizena dengan pengaturan suhu $80^{\circ} \mathrm{C}$ dan lama waktu gelatinisasi 4 menit menghasilkan beberapa gugus fungsi.

Tabel 6. Daerah serapan dan gugus fungsi yang terbentuk pada bioplastik

\begin{tabular}{ccc}
\hline $\begin{array}{c}\text { Bilangan Gelombang Komposit } \\
\begin{array}{c}\text { Glukomanan dan Maizena } \\
\left(80 \pm 1^{\circ} \mathrm{C}-4 \text { menit }\right)\end{array}\end{array}$ & $\begin{array}{c}\text { Daerah Serapan } \\
\left(\mathrm{cm}^{-1}\right)\end{array}$ & Gugus Fungsi \\
\hline 3666.68 & $3500-3700$ & $\mathrm{O}-\mathrm{H}$ alkohol \\
2638.62 dan 2736.99 & $2500-3000$ & asam \\
3155.54 & $3100-3500$ & $\mathrm{~N}-\mathrm{H}$ amida \\
2146,77 & $2140-2260$ & $\mathrm{C} \equiv \mathrm{C}$ alkuna \\
1697.36 & $1675-1725$ & $\mathrm{C}=\mathrm{O}$ keton \\
1122.57 dan 1176,65 & $1080-1300$ & $\mathrm{C}-\mathrm{O}$ ester \\
779.24 dan 862.18 & $675-995$ & $\mathrm{C}=\mathrm{C}$ alkena \\
$653.87 ; 441.70$ dan 495.71 & $<700$ & $-(\mathrm{CH} 2) \mathrm{n}$ \\
\hline
\end{tabular}

Gugus fungsi yang terbentuk pada komposit bioplastik yang terbaik digunakan untuk mengidentifikasi karakteristik profil permukaan dan gugus fungsi bioplastik yang terbuat dati komposit bioplastik glukomanan dan maizena (Harsojuwono dkk, 2016). Menurut Silverstein dan Robert (2005) daerah serapan $3500-3700 \mathrm{~cm}^{-1}$ dan 2500$3000 \mathrm{~cm}^{-1}$ menghasilkan gugus fungsi hidroksil $(\mathrm{O}-\mathrm{H})$ serta daerah serapan 10801300 menghasilkan gugus karboksil $(\mathrm{C}-\mathrm{O})$. Gugus amida $(\mathrm{N}-\mathrm{H})$ dihasilkan pada derah serapan 3100-3500 (Ningtyas, 2018), Menurut Underwood (2002) bilangan gelombang 2140-2260 $\mathrm{cm}^{-1}$ menghasilkan gugus alkuna $(\mathrm{C} \equiv \mathrm{C})$ dan daerah serapan 1675-1725 $\mathrm{cm}^{-1}$ menghasilkan gugus karbonil yang berikatan rangkap merupakan senyawa aromatik $(\mathrm{C}=\mathrm{O})$. Alkena merupakan senyawa aromatik $(\mathrm{C}=\mathrm{C})$ yang dihasilkan pada rentang daerah serapan $675-995 \mathrm{~cm}^{-1}$ dan Rentang daerah serapan kurang dari 700 $\mathrm{cm}^{-1}$ merupakan sumber senyawa hidrokarbon lain seperti $-(\mathrm{CH} 2) n$ (Thu, 2015). Menurut Harsojuwono dkk, (2018) bioplastik dengan rasio komposit pati, glukomanan dan karagenan $(4: 1: 1)$ menghasilkan gugus fungsi $\mathrm{O}-\mathrm{H}, \mathrm{C}-\mathrm{H}, \mathrm{C}-\mathrm{O}$, $(\mathrm{CH} 2)_{\mathrm{n}}$ dan $\mathrm{C}=\mathrm{C}$. Terdapat beberapa profi gugus fungsi komposit bioplastik 
glukomanan dan maizena yang sesuai dengan gugus fungsi yang dihasilkan pada penelitian tersebut yaitu gugus fungsi $\mathrm{O}-\mathrm{H}, \mathrm{C}-\mathrm{O}, \mathrm{C}=\mathrm{C}$ dan $-(\mathrm{CH} 2)$.

\section{KESIMPULAN DAN SARAN}

\section{Kesimpulan}

Berdasarkan hasil penelitian yang telah dilakukan dapat disimpulkan beberapa hal sebagai berikut:

1. Suhu dan waktu gelatinisasi serta interaksinya berpengaruh sangat nyata terhadap kuat tarik dan elastisitas. Suhu dan waktu gelatinisasi berpengaruh sangat nyata namun tidak berinteraksi terhadap perpanjangan saat putus serta tidak berpengaruh nyata terhadap swelling dan biodegradasi komposit bioplastik glukomanan dan maizena.

2. Komposit bioplastik glukomanan dan maizena terbaik terdapat pada perlakuan suhu $80 \pm 1{ }^{\circ} \mathrm{C}$ dan lama gelatinisasi 4 menit dengan karakteristik kuat tarik (3,390 MPa); elastisitas (35,811 MPa); perpanjangan saat putus $(12,3 \%)$; swelling $(68,13 \%)$; waktu degradasi 8 hari dan mengandung gugus fungsi hidroksil $(\mathrm{O}-\mathrm{H})$, amida $(\mathrm{N}-\mathrm{H})$, alkuna $(\mathrm{C} \equiv \mathrm{C})$, karbonil $(\mathrm{C}=\mathrm{O})$, karboksil $(\mathrm{C}-$ $\mathrm{O})$, alkena $(\mathrm{C}=\mathrm{C})$ dan hidrokarbon (CH2)n. Komposit bioplastik memiliki nilai kuat tarik, perpanjangan saat putus, elastisitas dan swelling yang belum memenuhi Jerman Institute for Standardization ISO 527/1B namun sudah memenuhi SNI biodegradasi.

\section{Saran}

Saran dari hasil penelitian yang telah dilakukan yaitu sebaiknya dilakukan perubahan bahan baku pati jagung (maizena) menjadi pati jagung termodifikasi dengan meubah gugus hidroksil yang telah teridentifikasi melalui reaksi kimia seperti esterifikasi, oksidasi atau dengan mengganggu struktur awalnya.

\section{DAFTAR PUSTAKA}

Anggraeni, D. A., S. B. Widjanarko, D. W. Ningtyas. 2014. Proporsi Tepung Porang (Amorphophallus muelleri Blume): Tepung Maizena terhadap Karakteristik Sosis Ayam. Jurnal Pangan dan Agroindustri. 2(3): p.214 223.

Arini, D., M. S. Ulum dan K. Kasman. 2017. Pembuatan dan Pengujian Sifat Mekanik Plastik Biodegradable Berbasis Tepung Biji Durian. Journal of Science and Technology. 6 (3): 276283.

Badan Standarisasi Nasional. 2014. Standar Nasional Indonesia (SNI) No. 7188.7:2011, Kriteria Ekolabel Bagian 7: Kategori Produk Kantong Belanja Plastik. Jakarta, Badan Standarisasi Nasional (BSN) ICS 13.020.50.

Carpenter, Grand, C.Y. Fred, Lee dan Chen. 1990. An 1800-V 300-A

Nondestructive Tester for Bioplolar Power Trasistors. IEEE Trasactions on Power Elektronics. 5(3): 314-322.

German Institute for Standardization. 2014. CEN TC 249 WG 13. German, Twinson (Best of Both Worlds).

Harsojuwono, B. A., I. W. Arnata dan S. Mulyani. 2018. Bio-Plastic Characteristics From Cassava Starch Modified in Variations The Temperature and $\mathrm{pH}$ of Gelatinization. Journal of Pharmaceutical, Biological and Chemical Sciences. 9 (2): 1 - 7.

Hasanah, Y. R dan Haryanto. 2017. Pengaruh Penambahan Filler Kalsium Karbonat $\left(\mathrm{CaCO}_{3}\right)$ dan Clay Terhadap Sifat Mekanik dan Biodegradable Plastik 
dari Limbah Tapioka. Jurnal Techno. 18 (2): 096-107.

Hayati, N dan Lazulva. 2018. Preparing of Cornstarch (Zea mays) Bioplastic Using $\mathrm{ZnO}$ Metal. Indoneisan Journal of Chemical Science and Technology. 1(1): 23-30.

Maekaji, K. 1978. Relationship Between Degree of Deacetylation and Gelationof Konjac Mannan - Kinetic Study on Gelation of Konjac Mannan. Jurnal of Agricultural Cemical Society of Japan. 52(1): 513-517.

Ningtyas, R. O. A. 2018. Pengaruh Konsentrasi Karbopol dalam Preparasi Mucadhesive Microspheres Amoksisilin Terhidrat. Skripsi. Tidak dipublikasikan. Fakultas Farmasi. Universitas Jember, Jember.

Nisah, Khairun. 2017. Study Pengaruh Kandungan Amilosa dan Amilopektin Umbi-Umbian terhadap Karakteristik Fisik Plastik Biodegradable dengan Plasticizer Gliserol. Jurnal Biotik. 5(2): 106-113.

Pradipta, I. M. D dan L. J. Mawarni. 2012. Pembuatan dan Karakterisasi Polimer Ramah Lingkungan Berbahan Dasar Glukomanan Umbi Porang. Jurnal Sains dan Seni Pomits. 1(1): $1-6$.

Puspita, S. 2018. Indonesia Penyumbang Samplah Plastik Terbesar Kedua di Dunia. Kompas, Jakarta.

Radhiyatullah, A., Indriani, N dan Ginting, M. H. S. 2015. Pengaruh Berat Pati dan Volume Plasticizer Gliserol terhadap Karakteristik Film Bioplastik Pati Kentang. Jurnal Teknik Kimia. 4(3): 35-39.

Sakinah, A. R. dan Kurniawansyah, I. S. 2018. Isolasi, Karakteristik Sifat Fisikokimia dan Aplikasi Pati Jagung dalam Bidang Farmasetik. Jurnal Farmaka. 16 (2): 430 - 442.

Saputro, E. A., O. Lefiyanti dan I. E. Mastuti. 2014. Pemurnian Tepung Glukomanan dari Umbi Porang (Amorphophallus Muelleri Blume) Menggunakan Proses Ekstraksi/Leaching dengan Larutan Etanol. Simposium Nasional RAPI XIII. 13(1): 7-13.

Silverstein dan M. Robert. 2005. Spectrometric Identification of Organic Compounds Edisi Ke-7. Usa, John Wiley \& Sons Inc.

Syah, A. S. 2016. Karakteristik Mie Kering yang Disubstitusi Tepung Kecambah Jangung dengan Variasi Penambahan Tepung Porang (Amorphophallus onchophylus. Sripsi. Tidak dipublikasikan. Fakultas Teknologi Pertanian. Universitas Jember, Jember.

Thu, S. L. 2015. Modification of Cassava Starch for Biodagradable Plastic Preparation. MRes Thesis. Departement of Industrial Chemistry. University of Yangon, Myanmar.

Underwood, A. L dan R. A. Day. 2002. Analisis Kimia Kuantitatif. Jakarta, Erlangga.

Wahyu, M. K. 2008. Pemanfaatan Pati Singkong sebagai Bahan Baku Edible Film. Beswan Djarum, Bandung.

Widjanarko, S. B. dan M. Johanna 2015. Analisis Metode Kolorimetri dan Gravimetri Pengukuran Kadar Glukomanan pada Konjak (Amorphophallus Konjac). Jurnal Pangan dan Agroindustri. 3(4): 15841588.

Winarno, FG. 1997. Kimia Pangan dan Gizi. PT. Gramedia Pustaka Utama, Jakarta. 